\title{
DAUN KERSEN (Muntingia calabura L.) SEBAGAI ALTERNATIF TERAPI PADA PENDERITA GOUT ARTRITIS
}

\author{
Ilkafah ${ }^{1)}$ \\ ${ }^{1)}$ Fakultas Keperawatan Universitas Hasanuddin
}

\begin{abstract}
Gout is a disease that is often suffered by the elderly. Pain is a commonly reported and is caused by increasing uric acid in the blood. Allopurinol is one of the drugs choice for people with gout but that has some side effects so it needs other alternative treatments. Herbal therapy is one type of complementary therapies in nursing, one of which is Muntingia calabura $L$. The aim of this study was to see the difference in effectiveness of Muntingia calabura L. and allopurinol in reducing uric acid and pain scale in gout patients in Tamalanrea Makassar. This study used an experimental design, randomized two-group design by giving Muntingia calabura L. on 22 respondents and allopurinol $100 \mathrm{mg}$ (twice in one day) in 22 respondents selected by simple random sampling with criterion of sample were pain scale on 1-6 and uric acid value were $>6.5 \mathrm{mg} / \mathrm{dl}$ (for female); $>7.5 \mathrm{mg} / \mathrm{dl}$ (for male). Giving Muntingia calabura L. for 3 weeks drunk twice in one day. Measurement of pain using Visual Analog Scale (VAS). Uric acid level were measured using laboratory tests. The data were analyzed by paired sample t-test for each intervention and by independent t-test to see the effectiveness difference of both therapies with significant level $\alpha<0,05$. The statistical results showed a decrease in joint pain scale in cherry leaf group $(p=0,00)$, but no decrease of pain in allopurinol administration $(\mathrm{p}=0.07)$. Both interventions had an effect on decreasing uric acid value $(p=0,00)$ There was a difference in decreasing the pain scale of both interventions but there was no difference to the decrease in uric acid value.It requires further research upon the benefits of Muntingia calabura $L$.
\end{abstract}

Keywords: Gout, Muntingia calabura L., Pain Scale, Uric Acid Level

\begin{abstract}
ABSTRAK
Gout merupakan penyakit yang sering diderita oleh lansia. Nyeri merupakan keluhan yang sering dilaporkan. Nyeri tersebut diakibatkan tinginya asam urat dalam darah. Allopurinol salah satu obat pilihan bagi penderita gout tetapi obat tersebut memiliki beberapa efek samping sehingga diperlukan terapi lain selain obat. Terapi herbal adalah salah satu jenis terapi komplementer dalam keperawatan, salah satunya adalah daun kersen. Tujuan penelitian ini adalah untuk melihat perbedaan efektivitas daun kersen dan obat allopurinol dalam menurunkan nilai asam urat dan skala nyeri pada penderita gout di Tamalanrea Makassar. Desain penelitian yang digunakan adalah Experimental Design, rancangan penelitian Randomized Two-group Design dengan cara memberikan rebusan daun kersen pada 22 responden dan obat allopurinol $100 \mathrm{mg}$ (2x sehari) pada 22 responden yang dipilih melalui teknik acak yaitu simple random sampling dengan kriteria sampel skala nyeri 1-6 dan nilai asam urat $>6,5 \mathrm{mg} / \mathrm{dl}$ (bagi wanita); $>7,5 \mathrm{mg} / \mathrm{dl}$ (bagi pria). Pemberian air rebusan daun kersen selama 3 minggu diminum 2x sehari. Pengukuran nyeri sendi menggunakan Visual Analog Scale (VAS). Kadar asam urat diukur menggunakan pemeriksaan laboratorium. Analisis penelitian untuk setiap intervensi menggunakan uji Paired Sample T-test dan untuk melihat perbedaan efektivitas kedua terapi menggunakan independent t-test dengan tingkat signifikan $\alpha<$ 0,05 . Uji statistik menunjukkan ada penurunan skala nyeri sendi pada kelompok rebusan daun kersen $(p=$ $0,00)$, tetapi tidak ada penurunan nyeri pada pemberian allopurinol $(\mathrm{p}=0,07$. Kedua intervensi berpengaruh terhadap penurunan nilai asam urat $(p=0,00)$. Ada perbedaan penurunan skala nyeri dari kedua intervensi tetapi tidak ada perbedaan untuk penurunan nilai asam urat. Diperlukan penelitian lanjutan mengenai manfaat tanaman kersen
\end{abstract}

Kata Kunci : Daun karsen, Gout, Nilai Asam Urat, Skala Nyeri 


\section{PENDAHULUAN}

Meningkatnya jumlah lansia menimbulkan masalah terutama dari segi kesehatan dan kesejahteraan lansia. Keberadaan penyakit mempengaruhi kondisi kesehatan fisik seseorang yang merupakan salah satu aspek yang menentukan kualitas hidup seseorang. Salah satu penyakit yang sering diderita adalah gout arthritis yang ditandai dengan meningkatnya kadar asam urat yang dipengaruhi oleh asupan makanan tinggi purin (Junaidi, 2013).

Angka prevalensi gout di dunia secara global belum tercatat, namun di Amerika Serikat angka prevalensi gout pada tahun 2010 sebanyak 807.552 orang $(0,27 \%)$ dari 293.655.405 orang. Indonesia menempati peringkat pertama di kawasan Asia Tenggara dengan angka prevalensi 655.745 orang $(0,27 \%)$ dari 238.452 .952 orang. Menurut Badan Penelitian dan Pengembangan Departemen Kesehatan, penyakit Osteoarthritis (OA) menduduki peringkat pertama sebesar $50-60 \%$, yang kedua adalah kelompok rematik luar sendi (gangguan pada komponen penunjang sendi dan peradangan) dan yang ketiga adalah gout sekitar 6-7\%. Sementara penyakit rematoid arthritis di Indonesia hanya 0,1\% (1 diantara 1000-5000 orang) (Lutfi, 2016). Berdasarkan Riskesdas (2015), penyakit sendi secara nasional prevalensinya berdasarkan diagnosa atau gejala $24,7 \%$ dan prevalensi berdasarkan diagnosis tenaga kesehatan adalah $11,9 \%$. Sulawesi memiliki prevalensi 10,3\% diagnosis penyakit sendi.

Gout arthritis merupakan penyakit metabolik yang ditandai dengan endapan urat sendi sehingga sendi artritis terasa menyakitkan (Junaidi, 2013). Penyakit ini disebabkan oleh produksi asam urat berlebih, ekskresi asam urat yang kurang atau keduanya serta adanya penyakit lain yang menyebabkan peningkatan asam urat di dalam tubuh (Paramita, 2011).

Pengobatan secara farmakologi pada gout meliputi pemberian obat-obatan seperti : NSAID (Non Seroiddal Anti Inflamatory), probenesid, sulfinpirazone, corticosteroid, serta allopurinol yang paling banyak digunakan. Allopurinol mempunyai fek samping berupa sakit perut, mual, mengantuk dan diare. Oleh karena itu diperlukan pengobatan nonfarmakologi yang memberikan efek jangka panjang dan minim efek samping antara lain adalah dengan pengobatan herbal dalam hal ini dengan menggunakan rebusan air daun Kersen.

Kersen merupakan tanaman buah tropis yang mudah dijumpai di pinggir jalan. Nama tanaman ini berbeda-beda di beberapa daerah, antara lain kerukup siam (Malaysia), jamaican cherry (Inggris), talok (Jawa), dan ceri (Kalimantan). Kersen memiliki ukuran kecil, pohonnya selalu hijau terus menerus, berbunga dan berbuah sepanjang tahun. Daun Kersen mengandung senyawa flavonoid, tannin, triterpene, saponin, polifenol yang menunjukkan adanya aktivitas antioksidati. Senyawa flavonoid dapat menurunkan kadar asam urat melalui penghambatan enzim xantin oksidase yaitu enzim yang berperan sebagai katalisator dalam proses oksidasi hipoxantin menjadi xantin dan kemudian menjadi asam arat. Selain itu, flavonoid dapat berfungsi sebagai antimikrobia, antivirus, antioksidan, antihipertensi, merangsang pembentukan estrogen dan mengobati gangguan fungsi hati. Flavonoid merupakan senyawa fenol mempunyai ciri adanya cincin piran yang menghubungkan rantai tiga karbon dengan salah satu cincin benzene (Binawati dan Amilah, 2013).

Daun kersen juga mempunyai banyak kasiat di antaranya sebagai anti septik, anti inflamasi, anti tumor, dan anti asam urat 
(Meiliza dan Hariyatmi, 2013). Sifat antiinflamasi (anti peradangan) pada daun Kersen dapat menghambat terjadinya peradangan di daerah-daerah sendi sehingga mengurangi nyeri pada penderita (Noorhamdani, Yosef dan Rosalia, 2014).

Penelitian tentang daun Kersen sudah banyak dilakukan pada hewan coba. Penelitian yang dilakukan oleh Sulistyowati (2009) dan Sunarni, pramono dan Asmah (2007) bahwa pemberian ekstrak daun kersen memberikan efek terhadap tikus putih dalam menurunkan kadar asam urat serum. Dalam penelitian Kholifaturrokhmah dan Purnawati (2016) didapatkan bahwa daun dan buah Kersen dapat menurunkan hiperuisemia pada mencit. Penelitian daun kersen pada manusia dilakukan oleh Zahroh (2016) didapatkan bahwa daun Kersen dapat menurunkan kadar glukosa darah.

Pemanfaatan daun kersen untuk olahan pangan juga sudah banyak dilakukan antara lain sebagai permen jelly (Huda, Sahputra, Anggono, Wahyuni, 2015), dibuat sebagai minuman teh (Lathief, 2016) dan juga sebagai kripik selai dan teh seduh (Laswati, Sundari, Anggraini, 2017). Daun kersen juga diolah sebagai cairan sanitasi tangan (Lestari dan Jacqueline, 2016). Dengan demikian daun kersen telah dibuktikan aman dikonsumsi oleh manusia. Pengolahan daun Kersen dapat dilakukan dengan merebus 50-100 mg daun tua yang telah dicuci bersih dan direbus dalam 1000 $\mathrm{ml}$ air hingga mendidih sampai tersisa separuhnya. Kandungan antioksidan terutama flavonoid paling tinggi pada daun yang sudah tua (Lathief, 2016)

Penelitian tentang daun Kersen terhadap nyeri dan nilai asam urat pada manusia belum dilakukan tetapi sudah ada dasar penelitian pada hewan coba dan pada manusia dengan diabetes mellitus, selain itu juga daun kersen dimanfaatkan sebagai pangan untuk manusia. Terapi herbal merupakan terapi komplementer keperawatan dan daun Kersen mudah didapatkan tanpa biaya, mudah tumbuh, selalu ada di semua tempat dan sepanjang waktu. Oleh karena itu peneliti memilih daun kersen dan tertarik melihat pengaruh rebusan daun kersen terhadap penurunan skala nyeri dan nilai asam urat pada penderita gout.

\section{METODE PENELITIAN}

Jenis penelitian yang digunakan adalah studi komparasi dengan desain penelitian Experimental Design dengan rancangan penelitian Randomized Twogroup Design yang memiliki dua kelompok. Kedua kelompok ini akan diberikan perlakuan (kelompok pertama dengan meminum rebusan daun kersen, kelompok kedua diberikan obat allopurinol dengan dosis $100 \mathrm{mg}$ dua kali sehari selama 3 minggu). Hasil perubahan skala nyeri dan nilai asam urat kedua kelompok tersebut yang akan diperbandingkan.

Populasi dalam penelitian ini adalah semua lansia yang mengalami nyeri sendi dan peningkatan asam urat darah di wilayah kerja puskesmas Tamalanrea Makassar berjumlah 68 orang. Sampel yang didapatkan peneliti sebesar 42 orang dengan metode simple random sampling yang dibagi menjadi 2 kelompok. Kriteria sampel adalah lansia berumur $\geq 55$ tahun dengan skala nyeri sendi 1-6 dan nilai asam urat > $6,5 \mathrm{mg} / \mathrm{dL}$ pada wanita dan $>7,5 \mathrm{mg} / \mathrm{dL}$ pada pria. Kriteria eksklusi adalah lansia yang mempunyai riwayat gastritis, mempunyai riwayat penyakit hati dan ginjal, dan penderita gout dengan tofus.

Pengumpulan data dilakukan dengan cara mengukur skala nyeri sebelum dan 
setelah diberikan intervensi pada masingmasing sampel menggunakan Visual Analog Scale (VAS) yang berupa suatu garis lurus yang panjangnya $10 \mathrm{~cm}(0-10)$ dan nilai asam urat darah sebelum dan sesudah intervensi dengan menggunakan jasa laboratorium. Selain pengukuran pada awal dan akhir setelah 2 minggu intervensi, responden juga akan diukur skala nyeri pada tiap minggu intervensi dan 3 minggu setelah intervensi. Selanjutnya data yang diperoleh ditulis pada lembar observasi pengukuran skala nyeri dan nilai asam urat. Intervensi dilakukan dengan merebus daun Kersen yang sudah tua sebanyak $100 \mathrm{mg}$ dengan $1000 \mathrm{ml}$ air hingga mendidih sampai tersisa $500 \mathrm{ml}$, biarkan hangat dan diminum selama 3 minggu (sehari $2 x$ pagi dan sore).

Untuk menganalisis perbedaan tiap kelompok digunakan paired t-tes test karena distribusi data normal, sedangkan untuk melihat perbedaan skala nyeri dan nilai asam urat pada kedua kelompok digunakan uji statistik independent t-test dengan tingkat signifikansi $\mathrm{p} \leq 0.05$ dan tingkat kepercayaan yaitu $95 \%$. Uji statistik tersebut dilakukan dengan bantuan komputer.

\section{HASIL PENELITIAN}

Distribusi data demografi responden pada penelitian ini, dari 42 responden dapat dilihat pada tabel di bawah ini

Tabel 1. Data demografi responden

\begin{tabular}{|c|c|c|c|c|c|c|}
\hline \multirow[b]{2}{*}{$\begin{array}{c}\text { Variabe } \\
1\end{array}$} & \multirow[b]{2}{*}{$\begin{array}{c}\text { Mea } \\
\mathbf{n}\end{array}$} & \multirow[b]{2}{*}{$\underset{\mathbf{n}}{\text { Media }}$} & \multirow[b]{2}{*}{ SD } & \multirow{2}{*}{$\begin{array}{c}\text { Min } \\
- \\
\text { Ma } \\
\text { x }\end{array}$} & \multicolumn{2}{|c|}{$95 \% \mathrm{CI}$} \\
\hline & & & & & Min & Max \\
\hline Umur & 62,55 & 64,50 & $\begin{array}{c}9,5 \\
0\end{array}$ & $\begin{array}{c}55- \\
74\end{array}$ & $\begin{array}{c}54,9 \\
6\end{array}$ & $\begin{array}{c}74,1 \\
4\end{array}$ \\
\hline
\end{tabular}

Tabel 2. Data demografi responden

\begin{tabular}{lcc}
\hline Variabel & Frekuensi & $\begin{array}{c}\text { Persentase } \\
(\mathbf{\%})\end{array}$ \\
\hline Jenis Kelamin & & \\
- Laki-laki & 19 & 45,2 \\
- Perempuan & 23 & 54,8 \\
\hline
\end{tabular}

\begin{tabular}{lcc}
\hline Pendidikan & & \\
- SD & 10 & 23,8 \\
- SMP & 11 & 26,2 \\
- SMA & 21 & 50 \\
\hline Pekerjaan & & \\
- IRT & 21 & 50 \\
- Pedagang & 21 & 50 \\
\hline Riwayat olahraga & & \\
- Tidak pernah & 12 & 28,6 \\
- Jarang (jalan kaki, senam) & 20 & 47,6 \\
- Selalu (jalan kaki, senam) & 10 & 23,8 \\
\hline
\end{tabular}

Data skala nyeri sebelum dan setelah pemberian rebusan daun Kersen dan allopurinol dapat dilihat pada table di bawah ini.

Tabel 3. Perbedaan skala nyeri sendi pre dan post intervensi menggunakan daun kersen $(n=22)$

\begin{tabular}{cccccc}
\hline Variabel & Mean & Median & SD & $\begin{array}{c}\text { Min } \\
-\end{array}$ & P \\
& & & & Max & \\
\hline Nyeri sebelum & 3,62 & 4,56 & 0,8 & $1-6$ & 0,00 \\
Nyeri setelah & 2,44 & 2,32 & 1,3 & $1-4$ & \\
\hline
\end{tabular}

Berdasarkan table 3 diatas didapatkan $\mathrm{p}$ value 0,00 yang berarti nilai $p 0,00<0,05$ sehingga dikatakan bahwa ada perbedaan nyeri sendi sebelum dan sesudah pemberian air rebusan daun kersen

Tabel 4. Perbedaan skala nyeri sendi pre dan post intervensi menggunakan allopurinol $(\mathbf{n}=22)$

\begin{tabular}{cccccc}
\hline Variabel & Mean & Median & SD & $\begin{array}{c}\text { Min } \\
- \\
\text { Max }\end{array}$ & P \\
\hline Nyeri sebelum & 3,89 & 3,96 & 0,8 & $1-6$ & 0,07 \\
Nyeri setelah & 3,76 & 3,32 & 1,3 & $1-6$ & \\
\hline
\end{tabular}

Berdasarkan tabel 3 diatas didapatkan $\mathrm{p}$ value 0,07 yang berarti nilai $p>0,05$ sehingga dikatakan bahwa tidak ada perbedaan nyeri sendi sebelum dan sesudah pemberian allopurinol.

Untuk melihat perbedaan efektivitas kedua terapi pada kedua kelompok perlakuan digunakan uji independent t-test didapatkan nilai $\mathrm{p}=0,08(\mathrm{p}>0,05)$ maka Ho ditolak yang artinya ada perbedaan penurunan skala nyeri yang diberikan terapi 
rebusan daun kersen dan pemberian allopurinol.

Data nilai asam urat sebelum dan setelah pemberian rebusan daun kersen dan allopurinol dapat dilihat pada tabel di bawah ini.

Tabel 5. Perbedaan nilai asam urat pre dan post intervensi menggunakan daun kersen $(n=22)$

\begin{tabular}{cccccc}
\hline Variabel & Mean & Median & SD & Min - Max & P \\
\hline $\begin{array}{c}\text { Asam urat } \\
\text { sebelum }\end{array}$ & 9,265 & 8,200 & $\begin{array}{c}1,94 \\
81\end{array}$ & $7,9-15$ & \\
Asam urat & 7,935 & 7,500 & $\begin{array}{c}1,25 \\
63\end{array}$ & $6,9-12$ & 0,00 \\
setelah & & & & \\
\hline
\end{tabular}

Berdasarkan tabel 5 diatas didapatkan $\mathrm{p}$ value 0,00 yang berarti nilai $p 0,00<0,05$ sehingga dikatakan bahwa ada perbedaan nilai asam urat sebelum dan sesudah pemberian air rebusan daun kersen

Tabel 6. Perbedaan nilai asam urat pre dan post intervensi menggunakan allopurinol $(\mathrm{n}=\mathbf{2 2})$

\begin{tabular}{cccccc}
\hline Variabel & Mean & Median & SD & Min - Max & P \\
\hline $\begin{array}{c}\text { Asam urat } \\
\text { sebelum }\end{array}$ & 8,98 & 8,6 & 0,6 & $8,2-14$ & \\
$\begin{array}{c}\text { Asam urat } \\
\text { setelah }\end{array}$ & 6,95 & 7,9 & 1,2 & $7,1-12$ & 0,00 \\
\hline
\end{tabular}

Berdasarkan tabel 6 diatas didapatkan p value 0,00 yang berarti nilai $p 0,00<0,05$ sehingga dikatakan bahwa ada perbedaan nilai asam urat sebelum dan sesudah pemberian allopurinol

Untuk melihat perbedaan efektivitas kedua terapi pada kedua kelompok perlakuan digunakan uji independent t-test didapatkan nilai $\mathrm{p}=0,00(\mathrm{p}>0,05)$ maka Ho diterima yang artinya tidak ada perbedaan nilai asam urat yang diberikan terapi rebusan daun Kersen dan pemberian allopurinol.

\section{PEMBAHASAN}

Hasil uji statistik pada kelompok yang mendapatkan intervensi minum rebusan daun Kersen mengalami penurunan skala nyeri yang signifikan, sedangkan kelompok dengan konsumsi obat allopurinol tidak mengalami penurunan skala nyeri yang bermakna yang berarti bahwa daun kersen lebih efektif dalam menurunkan nyeri pada penderita gout. Berbeda dengan penurunan nilai asam urat, kedua kelompok mengalami penurunan yang signifikan. Hal ini menunjukkan bahwa daun kersen sama efektifnya dengan obat allopurinol dalam menurunkan nilai asam urat darah.

Daun kersen lebih efektif dalam menurunkan skala nyeri penderita gout arthritis. Kandungan anti-inflamasi dan anti radang yang berupa flavonoid dan saponin merangsang pengeluaran endorphin (senyawa kimia untuk kekebalan tubuh) dan menghambat transmisi impuls nyeri ke otak sehingga perlahan-lahan nyeri akan berkurang (Noorhamdani, 2014). Selain itu, cara kerja senyawa flavonoid ini adalah dengan menghambat enzim xantin oksidase yg berperan dalam mempercepat dan memperburuk peradangan atau inflamasi pada penderita asam urat sehingga kadar asam urat dalam darah menurun (Rosalia, 2014).

Rentang skala nyeri pada kedua kelompok sebelum intervensi antara 1-6 dengan rata-rata skala nyeri 3,62, jika dikategorikan termasuk nyeri ringan dan nyeri sedang. Setelah dilakukan intervensi pada kelompok intervensi daun Kersen rentang nyeri berada pada angka 1-4 dengan rata-rata 2,44. Pada kelompok intervensi allopurinol, setelah diberikan intervensi, rentang skala nyeri tetap pada skala 1-6 dengan rata-rata 3,78. Secara angka ada sedikit penurunan tetapi secara klinis dan statistik tidak ada penurunan yang berarti

Pengobatan non farmakologi untuk nyeri memang akan sangat bermakna pada orang dengan nyeri ringan sampai sedang. 
Nyeri berat dengan skala 8-10 biasanya hanya mampu ditangani dengan pemberian analgesik. Meskipun metode penghilang nyeri secara nonfarmakologi memiliki resiko yang rendah tetapi dapat mempersingkat episode nyeri yang dirasakan dan memiliki efek jangka panjang daripada obat kimia.

Pengukuran skala nyeri tidak hanya dilakukan pada minggu ke-3 tetapi diukur setiap minggu. Pada kelompok dengan daun kersen ada penurunan skala nyeri bertahap dan dalam setiap minggu selalu ada penurunan meskipun ada beberapa responden yang tidak mengalami penurunan tetapi secara statistic tidak berpengaruh terhadap hasil uji. Ada 3 responden laki-laki yang tidak mengalami penurunan skala nyeri dan dari pengkajian riwayat olahraga didapatkan responden ini tidak pernah melakukan olahraga. Olahraga sangat penting bagi penderita gout karena dengan olahraga ringan misalnya jalan kaki sendi akan menjadi lentur dan nyeri bisa berkurang. Hasil wawancara dengan ke 3 responden juga didapatkan data bahwa responden sering makan makanan tinggi purin (kacang-kacangan, ikan teri, coto makassar dan kerang).. Makanan tinggi purin juga berkontribusi besar dalam peningkatan nilai asam urat dan nyeri responden.

Pada kelompok pemberian allopurinol ada beberapa responden mengalami penurunan, ada yang tetap dan bahkan ada yang bertambah nyeri. Beragamnya hasil perubahan nilai asam urat darah ini disebabkan karena aktivitas fisik (olahraga) dan berdasarkan wawancara dengan responden ada beberapa responden yang kurang baik dalam pengaturan pola makan seperti banyak mengkomsumsi daging, ikan laut, dan sayuran berupa kacang-kacangan, semua makanan ini banyak mengandung purin tinggi, dan juga setiap individu menghasilkan kadar endorphin dan tingkat peradangan atau inflamasi yang berbedabeda sehingga penurunan nyeri sendi dan kadar asam urat berbeda.

Hasil penelitian menunjukkan allopurinol efektif dalam menurunkan nilai asam urat darah tetapi tidak efektif dalam menurunkan nyeri. Sedangkan daun kersen efektif untuk keduanya. Untuk pengobatan nyeri sendi dengan allopurinol akan membutuhkan waktu lama berbulan-bulan sehingga dibutuhkan obat analgesik (Samiadi, 2017). Kersen sebagai alternative terapi gout efektif terhadap nyeri dan asam urat sehingga bisa dijadikan alternative pengobatan dan penatalaksannaan keluhan akibat gout. Obat tradisional yang menggunakan tanaman lebih rendah resikonya karena bersifat alami, tidak sekeras dengan obat kimia dan menurut Padmasari, Astuti dan warditiani (2013) karsen bersifat diuretik yaitu untuk menambah jumlah urin sehingga purin dalam darah dapat keluar. Obat-obatan tradisional atau obat-obatan herbal jika dikunsumsi rutin akan bisa digunakan sebagai alternative pengobatan. Hal ini juga dibuktikan dalam penelitian Ilkafah (2017) bahwa obat herbal daun sirsak juga dapat menurunkan nyeri dan nilai asam urat tetapi tidak diketahui bagaimana jika dibandingkan dengan obat-obatan kimia.

Hasil uji statistik independent t-test pada kedua kelompok menunjukkan ada perbedaan pada penurunan skala nyeri, sedangkan untuk penurunan asam urat tidak ada perbedaan antara kedua kelompok.

Kersen mengandung antiviral, antibakteri, juga ada zat yang disebut dapat menurunkan kadar asam urat pada darah, sehingga dapat mengurangi rasa nyeri pada sendi. Kersen juga mengandung flavonoid. Quercetin adalah sejenis flavonoid yang terkandung dalam buah kersen. Quercetin 
dapat menurunkan kadar asam urat darah. Kerja quercetin dalam menurunkan kadar asam urat adalah dengan cara menginhibisi aktivitas xantin oksidase yang merupakan enzim yang mensintesis asam urat (Kholifaturrokhmah dan Purnawati, 2016).

Kersen dan allopurinol sama-sama efektif dalam menurunkan nilai asam urat darah. Allopurinol merupakan obat pilihan bagi penderita gout. Tetapi kersen memiliki nilai lebih yaitu dapat menurunkan skala nyeri sehingga kersen bisa digunakan sebagai terapi alternatif pengganti allopurinol. Karsen juga tinggi akan antioksidan yang penting untuk penangkal radikal bebas (Mintawati, Kuntorini, maria, 2013).

Terapi komplementer dengan menggunakan bahan herbal memang minim efek samping tetapi perlu juga diperhatikan dan dipantau penggunaannya. Meskipun kersen aman dan efektif bagi penderita gout, penggunaan kersen perlu dibatasi karena terkait efeknya yang juga sebagai diuretik. Efek yang didapatkan pada beberapa responden adalah banyak kencing. Efek ini perlu diwaspadai pada responden yang membutuhkan cairan lebih sehingga penggunaannya tetap harus dalam pengawasan. Efek samping penggunaan kersen pada penelitian ini belum didapatkan karena intervensi dilakukan selama 3 minggu tetapi penggunaan dalam jangka waktu yang lama perlu diwaspadai terjadinya kekurangan cairan karena sifat kersen juga sebgai diuretik.

\section{KESIMPULAN}

Penanganan respon pasien merupakan inti intervensi keperawatan. Terapi komplementer berupa pemberian herbal daun Kersen dapat menurunkan nyeri pada penderita gout. Selain nyeri, kersen juga sebagai alternatif terapi dalam menurunkan kadar asam urat dalam darah.

\section{SARAN}

Diharapkan kersen bisa digunakan dalam terapi penderita gout dan dapat disosialisasikan kepada masyarakat. Perlu penelitian lanjutan melihat manfaat lain tanaman Kersen terhadap intervensi komplementer perawat. selain daun kersen, perlu penelitian lanjutan mengenai bagian lain dari tanaman kersen dalam hal ini adalah batang dan buah.

\section{DAFTAR PUSTAKA}

Binawati, D. K. \& Amilah, S. (2013). Effect of Muntinga calabura bioinsecticides extract towards mortality of worm soil (Agrotis ipsilon) and armyworm (Spodoptera exiqua) on plant leek (Allium fistolum). Wahana, 61(2), 51-57.

Ilkafah. 2017. Efektivitas Daun Sirsak Dalam Menurunkan Nilai Asam Urat Dan Keluhan Nyeri Pada Penderita Gout

Kelurahan Tamalanrea Makassar. Vol. 6 No. 2 MEI. PHARMACON Jurnal Ilmiah Farmasi - UNSRAT

Junaidi. (2013). Rematik dan Asam Urat. Jakarta: Bhuana Ilmu Populer.

Kholifaturrokhmah, I; Purnawati, R. 2016. Pengaruh Pemberian Ekstrak Buah Kersen (Muntingia Calabura L.) Dosis Bertingkat Terhadap Gambaran Histopatologi Ginjal Mencit 
Balb/C Yang Hiperurisemia. Jurnal Kedokteran Diponegoro Volume 5, Nomor 3, Agustus 2016 Online : http://ejournals1.undip.ac.id/index.php/medico

Laswati,D; Sundari, N; Anggraini, O. 2017. Pemanfaatan Kersen (Muntingia Calabura L.) Sebagai Alternatif Produk Olahan Pangan: Sifat Kimia Dan Sensoris. Jurnal JITIPARI Vol 4: 127-134

Lathief, Y. 2016. Pengaruh Lama Fermentasi Dan Variasi Konsentrasi Daun Kersen Terhadap Total Asam, Ph Dan Aktivitas Antioksidan Kefir Air The Daun Kersen. Skripsi. Universitas Islam Negri Maulana Malik Ibrahim. Malang

Lestari, Jacqueline. (2016). Dekok Daun Kersen (Muntingia Calabura) Sebagai Cairan Sanitasi Tangan Dan Buah Apel Manalagi (Malus sylvestris). Fakultas Teknobiologi, Universitas Atma Jaya Yogyakarta . UAJY Repository. $\quad$ http://ejournal.uajy.ac.id. Di akses tanggal 13 februari 2017

Lutfi Chabib, Z. I. (2016). Review Rheumatoid Arthritis: Terapi Farmakologi, Potensi Kurkumin dan Analognya, serta Pengembangan Sistem Nanopartikel. Pharmascience, Vol 3, No. 1, Februari 2016, hal: 10 18 .

Meiliza, E.R., dan Hariyatmi, 2013. Pengaruh jus buah Kersen terhadap kadar asam urat.
Mintowati, E., Kuntorini, S., dan Maria. 2013. Struktur Anatomi dan Uji Aktivitas Antioksidan Ekstrak Metanol Daun Kersen (Muntingia calabura). Program Studi Biologi FMIPA Universitas Lambung Mangkurat. http://jurnal .fmipa. unila.ac.id/index.php/semirata/arti cle/download/685/505

Noorhamdani, Yosef dan Rosalia. 2014.Uji Ekstrak Daun Kersen (Muntingia calabura) Sebagai Antibakteri Terhadap Methicillin-Resistant Staphylococcus aureus (MRSA) Secara in Vitro

Padmasari, P D., Astuti, K W., Warditiani, N K. 2013. Skrining Fitokimia Ekstrak Etanol 70\% Daun Kersen (Muntingia Calabura L). Jurnal Farmasi Udayana 2 (4): 1-4. Diakses tanggal 3 maret 2017

Paramita. 2011. Nursing : Memahami Berbagai Macam Penyakit. Jakarta

Riskesdas, 2015. Riset Kesehatan Dasar Tentang Penyakit Sendi. Diakses dari www.litbang.depkes.go.id .Diakses Pada tanggal 30 januari 2017

Huda, S., Syahputra, Anggono, Wahyuni. 2015. Pemanfaatan Daun Kersen (Muntingia Calabura) Sebagai Permen Jelly Terhadap Daya Terima Konsumen. Teknologi Pangan Vol.6 No.1 .Di akses tanggal 15 maret 2017

Sulistyowati, V. Y. (2009). Efek Pemberian Ekstrak Etanol Daun Talok (Muntingia Calabura L.) Terhadap Kadar Asam Urat Serum Tikus Putih (Rattus Norvegicus L.) Galur Wistar 
Hiperurisemia. Jurusan Biologi FMIPA UNS Surakarta .

Sunarni, T., S.Pramono dan R.Asmah. 2007. Efek Pemberian Ekstrak Etanol Daun Talok (Muntingia Calabura L.) Terhadap Kadar Asam Urat Serum Tikus Putih (Rattus Norvegicus L.) Galur Wistar Hiperurikemia. Majalah Farmasi Indonesia 18(3):111-116.

Zahroh, R. 2016. Pemberian Rebusan Daun Kersen Menurunkan Kadar Glukosa Darah Pasien Diabetes Mellitus Tipe 2 (Influence Of The Cherry Decoction Leaves Decrease In Blood Glucose Levels). Journals of Ners Community . 